\title{
Geology and Assessment of Undiscovered Oil and Gas Resources of the Northwest Laptev Sea Shelf Province, 2008
}

Chapter $S$ of

The 2008 Circum-Arctic Resource Appraisal

Professional Paper 1824

U.S. Department of the Interior

U.S. Geological Survey 
COVER

Eocene strata along the north side of Van Keulenfjorden, Svalbard, include basin-floor fan, marine slope, and deltaic to fluvial depositional facies. The age and facies of these strata are similar to Tertiary strata beneath the continental shelves of Arctic Eurasia, thus providing an analog for evaluating elements of those petroleum systems. Relief from sea level to top of upper bluff is approximately 1,500 feet. Photograph by David Houseknecht. 


\section{Geology and Assessment of Undiscovered Oil and Gas Resources of the Northwest Laptev Sea Shelf Province, 2008}

By Timothy R. Klett and Janet K. Pitman

Chapter S of

The 2008 Circum-Arctic Resource Appraisal

Edited by T.E. Moore and D.L. Gautier

Professional Paper 1824 


\title{
U.S. Department of the Interior RYAN K. ZINKE, Secretary
}

\section{U.S. Geological Survey William H. Werkheiser, Acting Director}

\author{
U.S. Geological Survey, Reston, Virginia: 2017
}

For more information on the USGS — the Federal source for science about the Earth, its natural and living resources, natural hazards, and the environment-visit https://www.usgs.gov or call 1-888-ASK-USGS.

For an overview of USGS information products, including maps, imagery, and publications, visit https://store.usgs.gov.

Any use of trade, firm, or product names is for descriptive purposes only and does not imply endorsement by the U.S. Government.

Although this information product, for the most part, is in the public domain, it also may contain copyrighted materials as noted in the text. Permission to reproduce copyrighted items must be secured from the copyright owner.

Suggested citation:

Klett, T.R. and Pitman J.K., 2017, Geology and assessment of undiscovered oil and gas resources of the Northwest Laptev Sea Shelf Province, 2008, chap. S of Moore, T.E., and Gautier, D.L., eds., The 2008 Circum-Arctic Resource Appraisal: U.S. Geological Survey Professional Paper 1824, 13 p., https://doi.org/10.3133/pp1824S

ISSN 2330-7102 (online) 


\section{The 2008 Circum-Arctic Resource Appraisal}

\section{Chapters}

A. Introduction to the 2008 Circum-Arctic Resource Appraisal (CARA) Professional Paper By Donald L. Gautier and Thomas E. Moore

B. Methodology for Assessment of Undiscovered Oil and Gas Resources for the 2008 Circum-Arctic Resource Appraisal

By Ronald R. Charpentier

\section{North America}

C. Geology and Assessment of Undiscovered Oil and Gas Resources of the Chukchi Borderland Province, 2008

By Kenneth J. Bird and David W. Houseknecht

D. Geology and Assessment of Undiscovered Oil and Gas Resources of the Hope Basin

Province, 2008

By Kenneth J. Bird, David W. Houseknecht, and Janet K. Pitman

E. Geology and Assessment of Undiscovered Oil and Gas Resources of the Arctic Alaska Petroleum Province, 2008

By David W. Houseknecht, Kenneth J. Bird, and Christopher P. Garrity

F. Geology and Assessment of Undiscovered Oil and Gas Resources of the Yukon Flats Basin Province, 2008

By Kenneth J. Bird and Richard G. Stanley

G. Geology and Assessment of Undiscovered Oil and Gas Resources of the Northwest Canada Interior Basins Province, Arctic Canada, 2008

By Marilyn E. Tennyson and Janet K. Pitman

H. Geology and Assessment of Undiscovered Oil and Gas Resources of the Franklinian Shelf Province, Arctic Canada and North Greenland, 2008

By Marilyn E. Tennyson and Janet K. Pitman

I. Geology and Assessment of Undiscovered Oil and Gas Resources of the Sverdrup Basin Province, Arctic Canada, 2008

By Marilyn E. Tennyson and Janet K. Pitman

\section{Greenland}

J. Geology and Assessment of Undiscovered Oil and Gas Resources of the West GreenlandEast Canada Province, 2008

By Christopher J. Schenk 
K. Geology and Assessment of Undiscovered Oil and Gas Resources of the East Greenland Rift Basins Province, 2008

By Donald L. Gautier

\section{North Atlantic Ocean}

L. Geology and Assessment of Undiscovered Oil and Gas Resources of the Jan Mayen Microcontinent Province, 2008

By Thomas E. Moore and Janet K. Pitman

\section{Eurasia}

M. Geology and Assessment of Undiscovered Oil and Gas Resources of the Mezen' Basin Province, 2008

By Timothy R. Klett and Janet K. Pitman

N. Geology and Assessment of Undiscovered Oil and Gas Resources of the Timan-Pechora Basin Province, Russia, 2008

By Christopher J. Schenk

0. Geology and Assessment of Undiscovered Oil and Gas Resources of the East Barents Basins Province and the Novaya Zemlya Basins and Admiralty Arch Province

By Timothy R. Klett

P. Geology and Assessment of Undiscovered Oil and Gas Resources of the North Kara Basins and Platforms Province, 2008

By Timothy R. Klett and Janet K. Pitman

0. Geology and Assessment of Undiscovered Oil and Gas Resources of the Northern West Siberian Mesozoic Composite Total Petroleum System of the West Siberian Basin Province, Russia, 2008

By Christopher J. Schenk

R. Geology and Assessment of Undiscovered Oil and Gas Resources of the Yenisey-Khatanga Basin Province, 2008

By Timothy R. Klett and Janet K. Pitman

S. Geology and Assessment of Undiscovered Oil and Gas Resources of the Northwest Laptev Sea Shelf Province, 2008

By Timothy R. Klett and Janet K. Pitman

T. Geology and Assessment of Undiscovered Oil and Gas Resources of the Lena-Anabar Basin Province, 2008

By Timothy R. Klett and Janet K. Pitman 
U. Geology and Assessment of Undiscovered Oil and Gas Resources of the Tunguska Basin Province, 2008

By Christopher J. Wandrey and Timothy R. Klett

V. Geology and Assessment of Undiscovered Oil and Gas Resources of the Lena-Vilyui Basin Province, 2008

By Timothy R. Klett and Janet K. Pitman

W. Geology and Assessment of Undiscovered Oil and Gas Resources of the Laptev Sea Shelf Province, 2008

By Timothy R. Klett and Janet K. Pitman

X. Geology and Assessment of Undiscovered Oil and Gas Resources of the Zyryanka Basin Province, 2008

By Timothy R. Klett and Janet K. Pitman

Y. Geology and Assessment of Undiscovered Oil and Gas Resources of the East Siberian Sea Basin Province, 2008

By Kenneth J. Bird, David W. Houseknecht, and Janet K. Pitman

Z. Geology and Assessment of Undiscovered Oil and Gas Resources of the Vilkitskii Basin Province, 2008

By Kenneth J. Bird, David W. Houseknecht, and Janet K. Pitman

AA. Geology and Assessment of Undiscovered Oil and Gas Resources of the Long Strait Province, Russian High Arctic, 2008

By Kenneth J. Bird, David W. Houseknecht, and Janet K. Pitman

\section{Arctic Ocean}

BB. Geology and Assessment of Undiscovered Oil and Gas Resources of the Amerasia Basin Petroleum Province, 2008

By David W. Houseknecht, Kenneth J. Bird, and Christopher P. Garrity

CC. Geology and Assessment of Undiscovered Oil and Gas Resources of the LomonosovMakarov Province, Central Arctic Ocean, 2008

By Thomas E. Moore, Kenneth J. Bird, and Janet K. Pitman

DD. Geology and Assessment of Undiscovered Oil and Gas Resources of the Eurasia Basin Province, Eastern Arctic Ocean, 2008

By Thomas E. Moore and Janet K. Pitman 


\section{Contents}

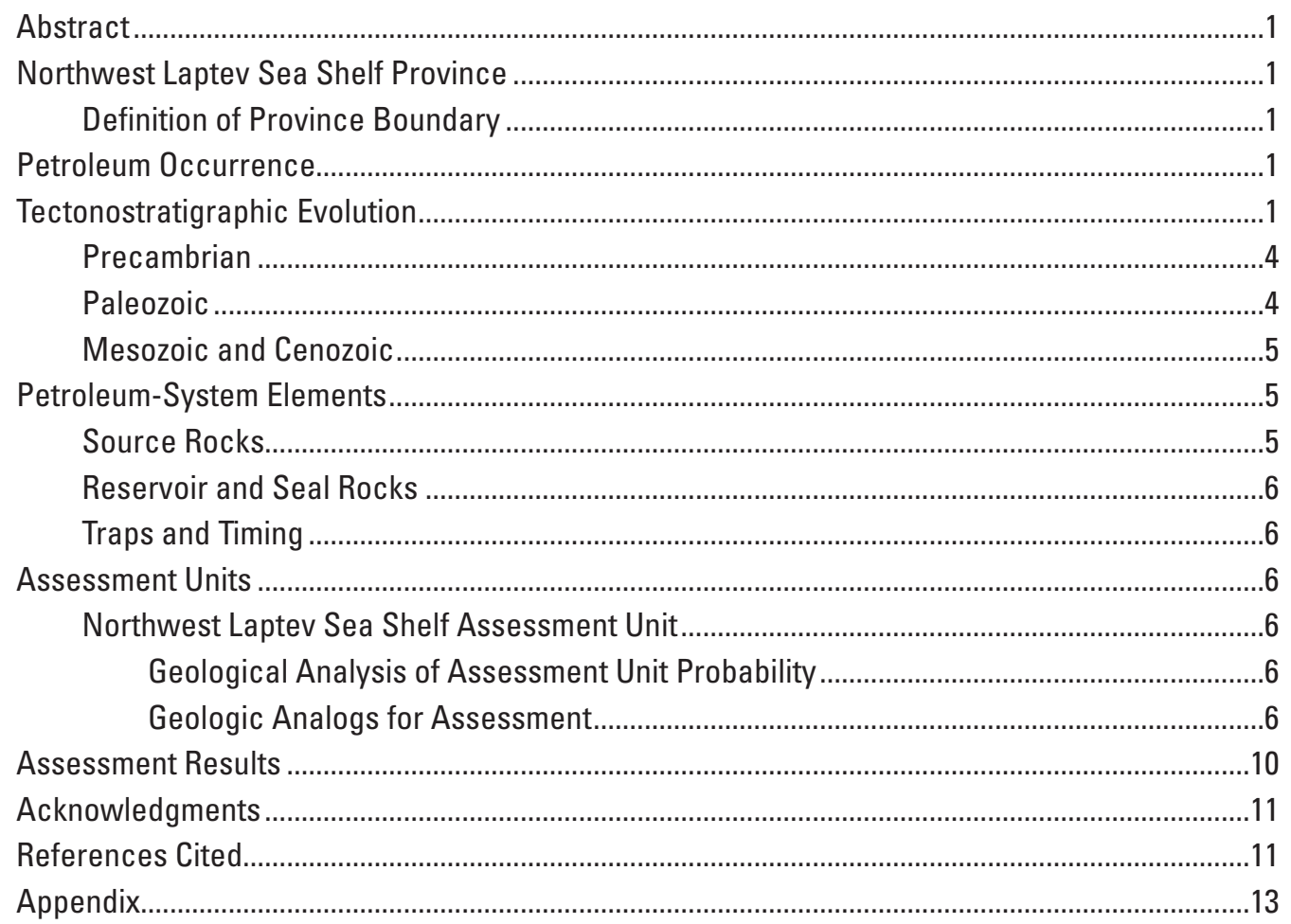

\section{Appendix}

[Available for download at https://doi.org/10.3133/pp1824S]

1. Input Data for the Northwest Laptev Sea Shelf Assessment Unit 


\section{Figures}

1. Map of the Arctic showing location of Northwest Laptev Shelf Province and Assessment

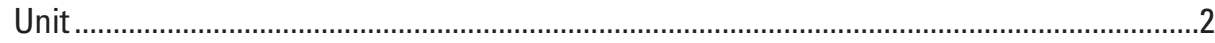

2. Map of Northwest Laptev Sea Shelf Province showing major structural features and location of geologic cross sections used in assessment........................................................

3. Regional geologic cross sections of the Northwest Laptev Sea Shelf ......................................

4. Lithostratigraphic column and Total Petroleum System events chart for the Northwest Laptev Sea Shelf Province ................................................................................................

\section{Tables}

1. Rifted passive margins used as geologic analogs for the Northwest Laptev Sea Shelf Assessment Unit

2. Field densities, median oil- and gas-field sizes, and exploration maturities of geologic analogs used for the North Kara Basins and Platforms Assessment Unit ..............................9

3. World statistics for oil and gas coproduct ratios, ancillary data, and depths .........................10

4. Assessment results for the Northwest Laptev Sea Shelf Province..........................................11 



\title{
Chapter S
}

\section{Geology and Assessment of Undiscovered Oil and Gas Resources of the Northwest Laptev Sea Shelf Province, 2008}

\author{
By Timothy R. Klett and Janet K. Pitman
}

\begin{abstract}
The U.S. Geological Survey (USGS) has recently assessed the potential for undiscovered oil and gas resources in the Northwest Laptev Sea Shelf Province as part of the USGS Circum-Arctic Resource Appraisal. The province is in the Russian Arctic, east of Severnaya Zemlya and the Taimyr fold-and-thrust belt. The province is separated from the rest of the Laptev Sea Shelf by the Severnyi transform fault. One assessment unit (AU) was defined for this study: the Northwest Laptev Sea Shelf AU. The estimated mean volumes of undiscovered petroleum resources in the Northwest Laptev Sea Shelf Province are approximately 172 million barrels of crude oil, 4.5 trillion cubic feet of natural gas, and 119 million barrels of natural-gas liquids, north of the Arctic Circle.
\end{abstract}

\section{Northwest Laptev Sea Shelf Province}

\section{Definition of Province Boundary}

The Northwest Laptev Sea Shelf Province in the Russian Arctic, situated along the east coast of the Taimyr Peninsula and Severnaya Zemlya (figs. 1, 2), extends from the Taimyr fold-and-thrust belt in the west to the shelf edge in the east. An east-west trending transform fault, called the Severnyi Transform, separates the Northwest Laptev Sea Shelf Province from the rest of the Laptev Sea Shelf, forming its south boundary. The province is mostly offshore in approximately $<100-\mathrm{m}$ water depth.

\section{Petroleum Occurrence}

As of 2008, no wells have been drilled in the Northwest Laptev Sea Shelf Province, and so any petroleum occurrence there is speculative.

\section{Tectonostratigraphic Evolution}

The Northwest Laptev Sea Shelf Province is interpreted as a rifted passive margin formed by the opening of the Eurasian Basin. The passive margin formed upon an extension of the Taimyr fold-and-thrust belt (fig. 2). To the south, the province is composed of extended continental crust and is a rift/ sag-style rather than a rifted passive margin (Sekretov, 2002) because of its position relative to the Cenozoic spreading center of the Eurasia Basin and the Gakkel Ridge. The few interpreted geophysical profiles of the province (Sekretov, 2002; Franke and Hinz, 2005) provide some information on its geologic structure. Geologic cross sections modified from the profiles presented by Sekretov (2002) are shown in figure 3 . The tectonostratigraphic evolution of the province was inferred from observations on the Taimyr Peninsula (Zonenshain and others, 1990; Vernikovsky, 1995, 1998; Sekretov, 2002).

The stratigraphic section in the Northwest Laptev Sea Shelf Province comprises Mesozoic and Cenozoic synrift and postrift sedimentary rocks overlying Proterozoic and Paleozoic prerift rocks that are the eastward extension of the Taimyr fold-and-thrust belt. The synrift and postrift succession is generally $<4 \mathrm{~km}$ thick (figs. 2, 3). An unconformity of unknown age caps the prerift succession. If the unconformity is Late Cretaceous and Paleogene (Franke and Hinz, 2005), then primarily Cenozoic rocks would overlay deformed Upper Jurassic and Lower Cretaceous complexes (Drachev and others, 1998). However, the unconformity might be as old as Late Triassic, as observed on the Taimyr Peninsula (Kontorovich and others, 1994; Girshgorn, 1996), and so the stratigraphic section would include Jurassic through Cenozoic rocks (fig. 3; Sekretov, 2002). In this study, most of the stratigraphic section involved with petroleum accumulation is presumed to be Upper Cretaceous and Cenozoic. 


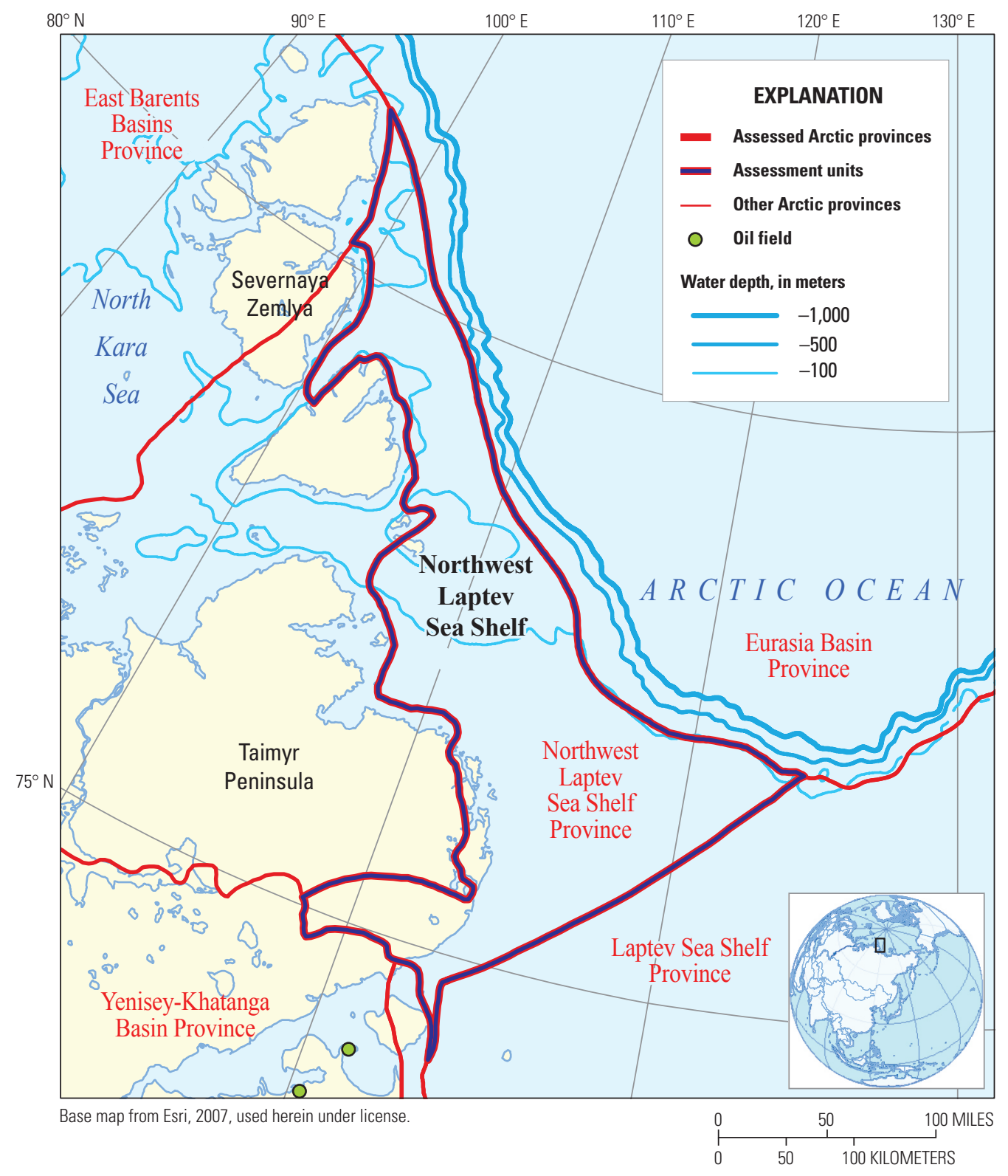

Figure 1. Map of the Arctic showing location of Northwest Laptev Shelf Province and Assessment Unit. Map from Persits and Ulmishek (2003); oil data from IHS Energy Group (2007). 


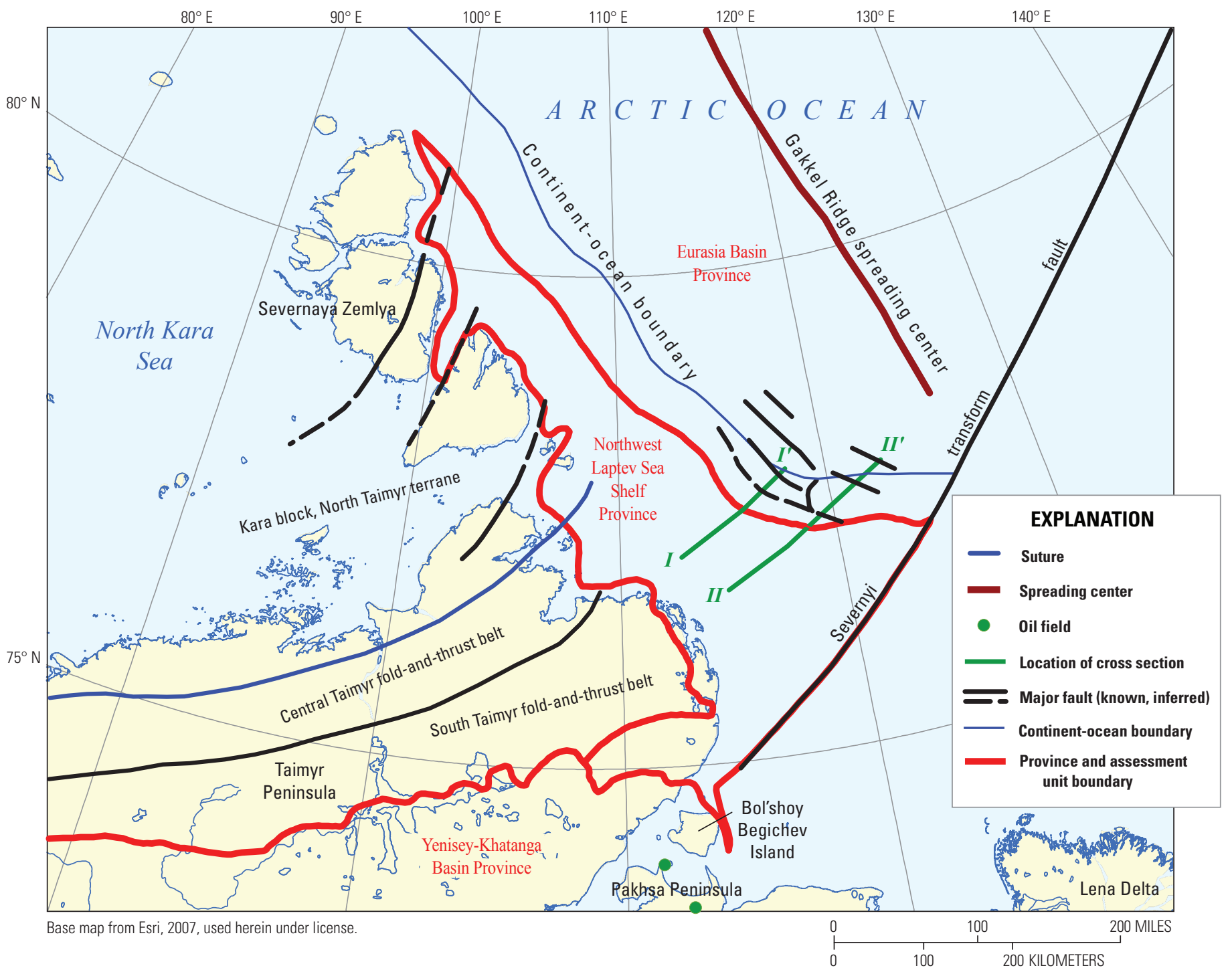

Figure 2. Map of Northwest Laptev Sea Shelf Province showing major structural features and location of geologic cross sections used in assessment. Data from Sekretov (2002), Persits and Ulmishek (2003), and IHS Energy Group (2007). 

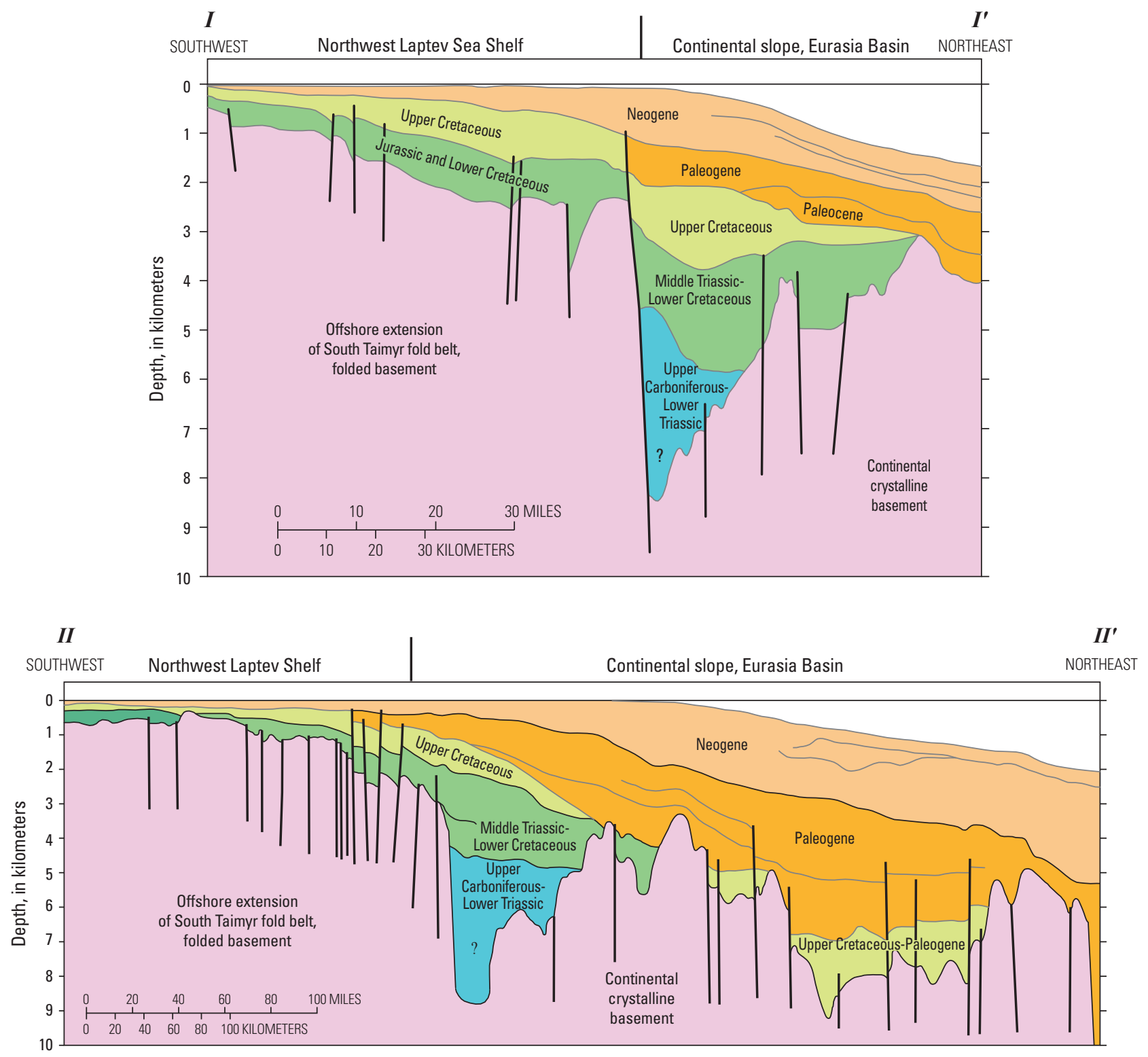

Figure 3. Regional geologic cross sections of the Northwest Laptev Sea Shelf (see fig. 2 for locations). Modified from Sekretov (2002).

\section{Precambrian}

The Taimyr Peninsula is divided into the North Taimyr, Central Taimyr, and South Taimyr terranes (Zonenshain and others, 1990). The North Taimyr terrane contains early Precambrian (2,400-2,200 Ma) crystalline rock and strongly deformed late Precambrian and possible Cambrian deepmarine sequences (Zonenshain and others, 1990). Riphean flyschoid rocks (sandstone and mudstone) are interpreted as continental-slope deposits (Zonenshain and others, 1990; Uflyand and others, 1991) that have been metamorphosed (Vernikovsky, 1995).

On the basis of isotopic-geochronologic data, Vernikovsky (1995) interpreted the Central Taimyr terrane as an accretionary prism formed by the collision of island arcs with continental blocks during the late Proterozoic. The
Central Taimyr terrane most likely collided with and joined the accreted South Taimyr terrane and the Siberian craton during the late Proterozoic, becoming part of the Siberian passive margin until the late Carboniferous (late Riphean, 600-570 Ma; Bogdanov and others, 1998; Vernikovsky, 1998; Torsvik and Andersen, 2002). However, early and middle Paleozoic ophiolites and subduction complexes have not been observed between the Central and South Taimyr terranes, indicating that the collision might have been oblique (Vernikovsky, 1998).

\section{Paleozoic}

Riphean and Paleozoic rocks of the North Taimyr terrane (part of the Kara block) were deposited along a passive margin (Uflyand and others, 1991). The Kara block (Metelkin and 
others, 2005; Zonenshain and others, 1990) was covered by a shallow sea in a platform setting during the Ordovician and Silurian.

The South Taimyr terrane became a passive margin on which as much as $4 \mathrm{~km}$ of shelf carbonates and mudstones were deposited during the Ediacaran throughVendian to middle Carboniferous (Kontorovich and others, 1994). The area was a northward-dipping (present day) monocline until the end of the late Paleozoic (Stepanenko, 1988). During the Devonian, however, the Siberian craton passed over a mantle plume (hot spot), causing magmatism and forming rift grabens between the South Taimyr terrane and the Siberian craton, beneath the present-day Yenisey-Khatanga Basin (fig. 2).

The Siberian craton collided with the Kara block in the Taimyr area beginning in the late Carboniferous (Vernikovsky, 1995, 1998; Bogdanov and others, 1998; Golonka and others, 2003). Although some researchers have suggested that this event was an extension of the Uralian collision (Zonenshain and Natapov, 1990; Vernikovsky, 1995; Inger and others, 1999; Gee and others, 2006), no Paleozoic oceanic rocks and Uralian collisional assemblages have been observed in the Taimyr fold-and-thrust belt (Gee and others, 2006; Lorenz and others, 2007). According to Vernikovsky (1995), late Carboniferous collision is responsible for the regional metamorphism, granitic intrusions, and transformation of the Siberian continental margin. The Kara block was uplifted and eroded at that time, shedding clastic sediment into the Sverdrup and Barents Basins and onto the South Taimyr passive margin (Zonenshain and Natapov, 1990).

From the Devonian through Triassic, the Siberian craton drifted northward, moving from warmer, dry climate in low to middle latitudes to cooler, humid climate in higher latitudes (Zonenshain and others, 1990). In the middle Carboniferous, carbonate deposition was replaced by deposition of terrigenous clastic sediment (Stepanenko, 1988; Kontorovich and others, 1994; Girshgorn, 1996).

Another extensional event that occurred during the late Permian and Early Triassic between the South Taimyr terrane and the Siberian craton might also have affected the southern part of the Northwest Laptev Sea Shelf Province. This event resulted in magmatism and volcanism in part of the South Taimyr terrane and the formation of the Yenisey-Khatanga Basin (fig. 2; Kontorovich and others, 1994; Girshgorn, 1996).

\section{Mesozoic and Cenozoic}

A major tectonic event (the early Kimmerian orogeny) associated with dextral transpression is assumed to have occurred during the Late Triassic and, possibly, into the Early Jurassic (Inger and others, 1999; Torsvik and Andersen, 2002). This event resulted in deformation of the Taimyr fold-andthrust belt (Torsvik and Andersen, 2002).

Localized Late Cretaceous inversion and folding occurred before the opening of the Eurasian Basin (Scott and others,
2003). Rifting might have begun as early as $64 \mathrm{Ma}$, with initial spreading at 56-58 Ma, younging southward (Sekretov, 2002). Oceanic spreading has continued until the present, though at progressively slower rates (Sekretov, 2002).

Thin strata of Upper Triassic through Cretaceous clastic rocks, Paleogene clastic rocks (mainly sandstone), and unconsolidated Pleistocene and Holocene clastic sediment are exposed on Severnaya Zemlya and the Taimyr Peninsula (Churkin and others, 1981). Upper Jurassic mudstone; unconsolidated Lower Cretaceous clastic sediment including Albian coal; and Pleistocene sand and gravel crop out on Bol'shoy Begichev Island, along the western province margin (fig. 2; Churkin and others, 1981). Mesozoic and Cenozoic strata thicken offshore, to $\sim 2.5 \mathrm{~km}$ on the Northwest Laptev Sea Shelf and $\sim 8 \mathrm{~km}$ on the continental slope (fig. 3 ).

The Northwest Laptev Sea Shelf Province has probably undergone periodic glaciation from the late Pliocene onward, but the thickness, duration, and extent of ice sheets are poorly constrained.

\section{Petroleum-System Elements}

Because the stratigraphic section in the Northwest Laptev Sea Shelf Province is thin $(<4 \mathrm{~km})$, any potential petroleum would have been generated off the shelf edge under a thicker sedimentary succession, migrating updip into marine shelf sedimentary deposits. A single Mesozoic and Cenozoic composite Total Petroleum System (TPS) was identified for the province, and lithostratigraphic column and a TPS events chart with petroleum-system elements is shown in figure 4 .

\section{Source Rocks}

Source rocks in the Northwest Laptev Sea Shelf Province are presumed to be Paleogene mudstone deposited during periods of restricted marine and anoxic conditions (Grantz and others, 2001), on the basis of the geochemical composition of organic matter in samples recovered from steep slopes of the Northwind and Lomonosov Ridges. Other potential source rocks include Lower and Upper Cretaceous and Paleogene gas-prone coaly and carbonaceous strata. Cretaceous coaly and carbonaceous clastic rocks are observed on Bol'shoy Begichev Island (fig. 2). Organic-rich and oil-prone Upper Jurassic marine mudstone crops out on Bol'shoy Begichev Island and the nearby Pakhsa Peninsula (fig. 2). The presence of these Mesozoic source rocks in the province, however, is unknown.

Cretaceous and Paleogene source rocks, deposited along the east edge of the province and on the continental slope outside the province, probably began to generate petroleum during the Paleogene and presently are still in the petroleumgeneration stage of maturity. Some petroleum may have migrated laterally updip into marine shelf sediment. 


\section{Reservoir and Seal Rocks}

If present, Jurassic and Lower Cretaceous sandstones constitute potential reservoirs in the Northwest Laptev Sea Shelf Province, similar to those in the neighboring YeniseyKhatanga Basin (Kontorovich and others, 1994). Younger strata are shallow and thin but might provide adequate reservoirs. Interbedded mudstone would provide seals. Potential reservoirs that could be present in the prerift section include Proterozoic and Paleozoic clastic and carbonate rocks in the folded basement.

Charging Mesozoic and older reservoir rocks with petroleum from younger source rocks can be problematic. Reservoir rocks must be juxtaposed with source rocks sometime during the structural formation of the area, unless petroleum migration occurred vertically through faults and fractures.

\section{Traps and Timing}

Traps for petroleum accumulation include extensional structures, such as normal faults and rollover anticlines and onlapped marine-shelf strata (pinchouts), that probably formed before and during petroleum generation.

\section{Assessment Units}

One assessment unit (AU), the Northwest Laptev Sea Shelf AU, was defined for the Northwest Laptev Sea Shelf Province. In this study, an AU is defined as a volume of rock within the TPS that has similar geologic characteristics. The estimated numbers and sizes of undiscovered petroleum accumulations in the AU are listed in the appendix, and the geologic analog data used to evaluate the AUs are summarized in tables 1 and 2 .

\section{Northwest Laptev Sea Shelf Assessment Unit}

The Northwest Laptev Sea Shelf AU coincides with the Northwest Laptev Sea Shelf Province and is the only AU in the province. The AU area is approximately $114,000 \mathrm{~km}^{2}$, 91 percent of which is offshore in the Laptev Sea. The AU is entirely north of the Arctic Circle. The stratigraphic section includes sedimentary rocks in the prerift, synrift, and postrift successions.

\section{Geological Analysis of Assessment Unit Probability}

No petroleum accumulations have been discovered, nor have any wells been drilled, in the Northwest Laptev Sea Shelf AU as of 2008. The probability that the AU contains at least one petroleum accumulation equal to or greater than the minimum field size of 50 million barrels of oil equivalent (MMBOE) is estimated at 40 percent (0.40). The input data are reported in the appendix and summarized below.

Charge Probability. - A charge probability of 0.50 was estimated because the presence of thermally mature source rocks in and adjacent to the AU has not been proved and petroleum migration into older Mesozoic reservoir rocks is problematic.

Rock Probability.-A rock probability of 0.80 was estimated. The existence of reservoir rocks and traps is inferred but has not been proved.

Timing and Preservation Probability.-A timing-andpreservation probability of 1.00 was estimated. Potential Mesozoic and Paleogene source rocks would have been mature by the end of the Paleogene, and traps associated with rifting and marine-shelf deposition were present before petroleum generation.

\section{Geologic Analogs for Assessment}

We used data for passive rift margins (table 1) from the U.S. Geological Survey (USGS) Analog Database (Charpentier and others, 2008) to estimate the number and size distributions of undiscovered petroleum accumulations in the Northwest Laptev Sea Shelf AU. The analog dataset contains 23 AUs representing extensional, rifted passive margins, with both clastic and carbonate rocks and no salt structures (table 1). Some AUs had early preextension compressional events. The analog AUs have discovered oil and gas fields larger than the minimum size defined for this assessment (50 MMBOE; table 1).

Number of Undiscovered Accumulations.-The number of undiscovered petroleum accumulations was estimated from field densities (estimated number of undiscovered accumulations plus number of discovered accumulations exceeding 50 MMBOE per 1,000 $\mathrm{km}^{2}$ ) contained in the analog dataset, which are as follows: (1) the median and maximum densities of discovered accumulations are 0.03 and 0.2 fields per $1,000 \mathrm{~km}^{2}$, respectively; and (2) the median and maximum densities of discovered plus undiscovered accumulations are 0.2 and 0.5 fields per $1,000 \mathrm{~km}^{2}$, respectively. Densities of 0.1 and 0.50 (median and maximum, respectively) were used in this assessment, approximating those of the analogs. The total minimum, median, and maximum number of undiscovered petroleum accumulations are 1, 10, and 60, respectively (see appendix). The minimum of one field was chosen as a default parameter. A gas-rich oil/gas mixture of 0.2 (from 0 to 0.5 ) was assumed because potential Cretaceous and Paleogene source rocks are most likely gas prone. The estimated number of undiscovered oil accumulations is 0 (minimum), 2 (median), and 30 (maximum) and the estimated number of undiscovered gas accumulations is 1 (minimum), 8 (median), and 60 (maximum) (appendix 1).

Sizes of Undiscovered Accumulations.-The minimum, median, and maximum sizes of undiscovered petroleum accumulations are reported in the appendix. The minimum sizes of undiscovered accumulations are 50 million barrels 




Figure 4. Lithostratigraphic column and Total Petroleum System events chart for the Northwest Laptev Sea Shelf Province. Source rocks column at far left shows the percent of the world's total petroleum reserves generated by source (modified from Ulmishek and Klemme, 1990). Average global temperature data is from Frakes and others (1992) and Barrett (2003). Sea level curve is from Golonka and Kiessling (2002) and Hardenbol and others (1998). Geologic time scale is that of Gradstein and others (2004). 
Table 1. Rifted passive margins used as geologic analogs for the Northwest Laptev Sea Shelf Assessment Unit.

[Analog data from Charpentier and others (2008)]

\begin{tabular}{|c|c|c|}
\hline Province (Assessment Unit) & Structural setting & Trap system \\
\hline Volga-Ural Region (10150102) & Compressional & Basement-involved block structures \\
\hline Ma'Rib-Al Jawf/Masila Basin (20040101) & Extensional & $\begin{array}{l}\text { Extensional grabens and other structures } \\
\text { related to normal faulting }\end{array}$ \\
\hline Widyan Basin-Interior Platform (20230101) & Extensional & Basement-involved block structures \\
\hline Widyan Basin-Interior Platform (20230201) & Extensional & Basement-involved block structures \\
\hline Pelagian Basin (20480101) & Compressional, Extensional & $\begin{array}{l}\text { Extensional grabens and other structures } \\
\text { related to normal faulting; Transtensional } \\
\text { and transpressional }\end{array}$ \\
\hline Pelagian Basin (20480201) & Compressional, Extensional & $\begin{array}{l}\text { Extensional grabens and other structures } \\
\text { related to normal faulting; Transtensional } \\
\text { and transpressional }\end{array}$ \\
\hline Red Sea Basin (20710101) & Extensional & $\begin{array}{l}\text { Extensional grabens and other structures } \\
\text { related to normal faulting }\end{array}$ \\
\hline Red Sea Basin (20710201) & Extensional & $\begin{array}{l}\text { Extensional grabens and other structures } \\
\text { related to normal faulting }\end{array}$ \\
\hline Bonaparte Gulf Basin (39100201) & Compressional & $\begin{array}{l}\text { Extensional grabens and other structures } \\
\text { related to normal faulting }\end{array}$ \\
\hline Bonaparte Gulf Basin (39100301) & Compressional & $\begin{array}{l}\text { Extensional grabens and other structures } \\
\text { related to normal faulting }\end{array}$ \\
\hline Browse Basin (39130101) & Extensional & $\begin{array}{l}\text { Extensional grabens and other structures } \\
\text { related to normal faulting }\end{array}$ \\
\hline Northwest Shelf (39480101) & Extensional & $\begin{array}{l}\text { Extensional grabens and other structures } \\
\text { related to normal faulting }\end{array}$ \\
\hline Northwest Shelf (39480201) & Extensional & $\begin{array}{l}\text { Extensional grabens and other structures } \\
\text { related to normal faulting }\end{array}$ \\
\hline Vestford-Helgeland (40170101) & Extensional & $\begin{array}{l}\text { Extensional grabens and other structures } \\
\text { related to normal faulting }\end{array}$ \\
\hline Guyana-Suriname Basin (60210103) & Unknown & Stratigraphic undeformed \\
\hline Foz do Amazonas Basin (60220101) & Extensional & Gravity-induced growth faults \\
\hline Sergipe-Alagoas Basin (60290101) & Extensional & Basement-involved block structures \\
\hline Sergipe-Alagoas Basin (60290102) & Extensional & Gravity-induced growth faults \\
\hline Santos Basin (60360101) & Passive & Stratigraphic undeformed \\
\hline East Venezuela Basin (60980201) & Compressional, Extensional & $\begin{array}{l}\text { Extensional grabens and other structures } \\
\text { related to normal faulting }\end{array}$ \\
\hline Tobago Trough (61030101) & Compressional, Extensional & $\begin{array}{l}\text { Extensional grabens and other structures } \\
\text { related to normal faulting }\end{array}$ \\
\hline West-Central Coastal (72030101) & Extensional & Basement-involved block structures \\
\hline Orange River Coastal (73030101) & Extensional & Stratigraphic undeformed \\
\hline Bombay (80430101) & Extensional & $\begin{array}{l}\text { Basement-involved block structures; strati- } \\
\text { graphic undeformed }\end{array}$ \\
\hline
\end{tabular}


Table 2. Field densities, median oil- and gas-field sizes, and exploration maturities of geologic analogs used for the Northwest Laptev Sea Shelf Assessment Unit.

[Analog data from Charpentier and others (2008). Rift-sag basin analogs are listed in table 1. Asterisk (*), not reported in analog database; BCF, billion cubic feet; MMB, millions of barrels; MMBOE, million barrels of oil equivalent; gas volumes are nonassociated].

\begin{tabular}{|c|c|c|c|c|c|}
\hline $\begin{array}{c}\text { Province } \\
\text { (Assessment Unit) }\end{array}$ & $\begin{array}{c}\text { *Field density: } \\
\text { number of } \\
\text { discovered fields } \\
>50 \text { MMBOE per } \\
1,000 \mathrm{~km}^{2}\end{array}$ & $\begin{array}{c}\text { Field density: } \\
\text { number of } \\
\text { discovered and } \\
\text { undiscovered fields } \\
>50 \mathrm{MMBOE} \\
\text { per } 1,000 \mathrm{~km}^{2}\end{array}$ & $\begin{array}{c}\text { Field size } \\
\text { distribution } \\
\text { median field size } \\
>50 \text { MMBOE }\end{array}$ & $\begin{array}{l}\text { Exploration } \\
\text { maturity, in } \\
\text { percent by } \\
\text { volume } \\
\text { in fields } \\
>50 \text { MMBOE }\end{array}$ & $\begin{array}{l}\text { Maximum field } \\
\text { size } \\
\text { (MMBOE) }\end{array}$ \\
\hline Volga-Ural Region (10150102) & 0.14 & 0.14 & 116 & 100 & - \\
\hline Ma'Rib-Al Jawf/Masila Basin (20040101) & 0.20 & 0.41 & 100 & 66 & - \\
\hline Widyan Basin-Interior Platform (20230101) & 0.02 & 0.16 & 109 & 19 & - \\
\hline Widyan Basin-Interior Platform (20230201) & 0.02 & 0.21 & 95 & 13 & - \\
\hline Pelagian Basin (20480101) & 0.12 & 0.19 & 157 & 94 & - \\
\hline Pelagian Basin (20480201) & 0.01 & 0.02 & 63 & 66 & - \\
\hline Red Sea Basin (20710101) & 1.66 & 2.76 & 129 & 85 & - \\
\hline Red Sea Basin (20710201) & 0.03 & 0.41 & 103 & 7 & - \\
\hline Bonaparte Gulf Basin (39100201) & 0.03 & 0.14 & 95 & 8 & - \\
\hline Bonaparte Gulf Basin (39100301) & 0.03 & 0.14 & 112 & 68 & - \\
\hline Browse Basin (39130101) & 0.02 & 0.14 & 125 & 48 & - \\
\hline Northwest Shelf (39480101) & 0.40 & 1.53 & 108 & 56 & - \\
\hline Northwest Shelf (39480201) & $>0.00$ & 0.02 & 111 & 41 & - \\
\hline Vestford-Helgeland (40170101) & 0.19 & 1.68 & 112 & 26 & - \\
\hline Guyana-Suriname Basin (60210103) & 0.01 & 0.02 & 136 & 63 & - \\
\hline Foz do Amazonas Basin (60220101) & 0.01 & 0.21 & 102 & 5 & - \\
\hline Sergipe-Alagoas Basin (60290101) & 0.22 & 0.25 & 85 & 100 & - \\
\hline Sergipe-Alagoas Basin (60290102) & 0.09 & 0.51 & 105 & 5 & - \\
\hline Santos Basin (60360101) & 0.02 & 0.82 & 121 & 0 & - \\
\hline East Venezuela Basin (60980201) & 0.79 & 1.35 & 119 & 70 & - \\
\hline Tobago Trough (61030101) & 0.38 & 0.94 & 128 & 42 & - \\
\hline West-Central Coastal (72030101) & 0.03 & 0.04 & 123 & 74 & - \\
\hline Orange River Coastal (73030101) & 0.00 & 0.01 & 110 & 50 & - \\
\hline Bombay (80430101) & 0.06 & 0.11 & 106 & 82 & - \\
\hline Median & 0.03 & 0.21 & 110 & 53 & 707 \\
\hline Mean & 0.19 & 0.51 & 111 & 35 & 917 \\
\hline
\end{tabular}


(MMB) of crude oil and 300 billion cubic feet (BCF) of natural gas (6 BCF equals $1 \mathrm{MMBOE})$. The median sizes of undiscovered accumulations are $110 \mathrm{MMB}$ of crude oil and $660 \mathrm{BCF}$ of natural gas. The median size of undiscovered oil fields (100 MMBOE) is slightly less than that of the analog dataset (110 MMBOE). The low-probability maximum field size (2,000 MMBOE) is less than the median of the maximum field sizes in the analog dataset (2,800 MMBOE; see appendix). The median and maximum sizes (660 BCF and $18,000 \mathrm{BCF}$, respectively) of undiscovered gas fields are greater than those of undiscovered oil fields because Cretaceous and Paleogene potential source rocks most likely are gas prone (see appendix).

Expected Maximum Undiscovered Accumulation Size.The expected maximum size of undiscovered gas accumulations (not reported in appendix) is based on the analog dataset: 3,000 BCF, or 18,000 MMBOE (table 2). The expected maximum size of undiscovered oil accumulations is $200 \mathrm{MMB}$.

Petroleum Composition and Properties of Undiscovered Accumulations.-Coproducts and petroleum-quality properties are derived from global statistics (table 3).

\section{Assessment Results}

The assessment results for the Northwest Laptev Sea Shelf Province and AU are summarized in table 4. Estimates represent undiscovered, technically recoverable, conventional petroleum resources.

The risked mean of undiscovered crude oil is $172 \mathrm{MMB}$, with a 95-percent chance (F95) of $0 \mathrm{MMB}$, a 50-percent chance (F50) of $0 \mathrm{MMB}$, and a five-percent chance (F5) of $894 \mathrm{MMB}$. The risked mean volume of undiscovered nonassociated natural gas is 4,488 BCF, with an F95 of $0 \mathrm{BCF}$, an $\mathrm{F} 50$ of $0 \mathrm{BCF}$, and an F5 of 20,427 BCF. The largest expected size of an undiscovered oil field is $\sim 232 \mathrm{MMB}$, and the largest expected size of an undiscovered gas field is $\sim 3,242 \mathrm{BCF}$ (not listed in table 4).

The geologic probabilities of the AUs in this study were determined on the basis of a consideration of the geology of each province and the geologic probabilities assigned to AUs in all Arctic basins. Using this approach, the probabilities were consistently applied throughout the Arctic region.

Table 3. World statistics for oil and gas coproduct ratios, ancillary data, and depths.

[Data from Charpentier and others (2008)]

\begin{tabular}{|c|c|c|c|}
\hline Variable & Minimum & Median & Maximum \\
\hline \multicolumn{4}{|l|}{ Coproduct ratios } \\
\hline Natural gas-to-crude oil ratio in oil accumulations (cubic feet per barrel) & 100 & 1,000 & 20,000 \\
\hline Natural gas liquids-to-natural gas ratio in gas accumulations (barrels per thousand cubic feet) & 5 & 25 & 75 \\
\hline \multicolumn{4}{|l|}{ Ancillary data for oil accumulations } \\
\hline Viscosity (centipoise) & 0.01 & 3 & 30 \\
\hline Sulfur content of oil (percent) & 0 & 0.3 & 1.5 \\
\hline \multicolumn{4}{|l|}{ Ancillary data for gas accumulations } \\
\hline Inert gas content (percent) & 0 & 2 & 10 \\
\hline Carbon dioxide content (percent) & 0 & 1.5 & 10 \\
\hline Drilling depth (meters) & 350 & 2,000 & 7,000 \\
\hline
\end{tabular}


Table 4. Assessment results for the Northwest Laptev Sea Shelf Province (conventional undiscovered resources).

[MMB, million barrels; BCF, billion cubic feet. Results shown are fully risked estimates. For gas fields, all liquids are included under the natural gas liquids (NGL) category. F95 denotes a 95-percent chance of at least the amount tabulated. Other fractiles are defined similarly. Fractiles are additive under the assumption of perfect positive correlation. TPS, total petroleum system; AU, assessment unit. Gray shading indicates not applicable. Numbers do not exactly add to the totals because totals were calculated by statistical aggregation.]

\begin{tabular}{|c|c|c|c|c|c|c|c|c|c|c|c|c|c|c|}
\hline \multirow{2}{*}{$\begin{array}{c}\text { Total petroleum } \\
\text { systems and } \\
\text { assessment units }\end{array}$} & \multirow{2}{*}{$\begin{array}{c}\text { AU } \\
\text { probability }\end{array}$} & \multirow{2}{*}{$\begin{array}{l}\text { Field } \\
\text { type }\end{array}$} & \multicolumn{4}{|c|}{ Oil (MMB) } & \multicolumn{4}{|c|}{ Gas (BCF) } & \multicolumn{4}{|c|}{ NGL (MMB) } \\
\hline & & & F95 & $\mathrm{F} 50$ & F5 & Mean & F95 & F50 & F5 & Mean & F95 & $\mathrm{F} 50$ & F5 & Mean \\
\hline \multicolumn{15}{|c|}{ Assessment results-entire province; Mesozoic-Cenozoic composite total petroleum system } \\
\hline \multirow{2}{*}{$\begin{array}{l}\text { Northwest Laptev } \\
\text { Sea Shelf AU }\end{array}$} & 0.4 & Oil & 0 & 0 & 894 & 172 & 0 & 0 & 1,435 & 267 & 0 & 0 & 38 & 7 \\
\hline & & Gas & N/A & $\mathrm{N} / \mathrm{A}$ & $\mathrm{N} / \mathrm{A}$ & N/A & 0 & 0 & 18,992 & 4,221 & 0 & 0 & 513 & 112 \\
\hline $\begin{array}{l}\text { Total } \\
\text { conventional } \\
\text { resources }\end{array}$ & & & 0 & 0 & 894 & 172 & 0 & 0 & 20,427 & 4,488 & 0 & 0 & 551 & 119 \\
\hline
\end{tabular}

\section{Acknowledgments}

We are extremely grateful to the USGS Library staff for their help in obtaining rare, hard-to-find geologic articles from the Russian scientific literature. We also thank Feliks Persits for GIS support, and Donald L. Gautier and Gregory F. Ulmishek for their reviews of the manuscript.

\section{References Cited}

Barrett, P., 2003, Paleoclimatology—cooling a continent: Nature, v. 421, p. 221-223.

Bogdanov, N.A., Khain, V.E., Vernikovsky, V.A., Drachev, S.S., Kostyuchenko, S.L., Kouzmichev, A.B., Rosen, O.M., Sekretov, S.B., Senin, B.V., and Shipilov, E.V., 1998, Continental accretion in the Taymyr part of the Eurasian Basin margin [abs.]: Proceedings of the third International Conference on Arctic Margins, Celle, Germany.

Charpentier, R.R., Klett, T.R., and Attanasi, E.D., 2008, Database for assessment unit-scale analogs, exclusive of the United States: U.S. Geological Survey Open-File Report 2007-1404, 61 p.

Churkin, M., Jr., Soleimani, G., Carter, C., and Robinson, R., 1981, Geology of the Soviet Arctic: Kola Peninsula to Lena River, in Nairn, A.E.M., Churkin, M., Jr., and Stehli, F.G., eds., The Arctic Ocean, v. 5 of The ocean basins and margins: New York, Plenum Press, p. 331-376.

Drachev, S.S., Savostin, L.A., Groshev, V.G., and Bruni, I.E., 1998, Structure and geology of the continental shelf of the Laptev Sea, Eastern Russian Arctic: Tectonophysics, v. 298, no. 4, p. 357-393.
Frakes, L.A., Francis, J.E., and Syktus, J.I., 1992, Climate modes of the Phanerozoic - the history of the earth's climate over the past 600 million years: Cambridge, U.K., Cambridge University Press, 274 p.

Franke, D., and Hinz, K., 2005, The structural style of sedimentary basins on the shelves of the Laptev Sea and western East Siberian Basin, Siberian Arctic: Journal of Petroleum Geology, v. 28, no. 3, p. 269-286.

Gee, D.G., Bogolepova, O.K., and Lorenz, H., 2006, The Timanide, Caledonide and Uralide Orogens in the Eurasian high Arctic, and relationships to the palaeocontinents Laurentia, Baltica and Siberia, in Gee, D.G., and Stephenson, R.A., eds., European lithosphere dynamics: Memoirs of the Geological Society of London Memoir 32, p. 507-520.

Girshgorn, L. Sh., 1996, Sovremennyye geofizicheskiye metody pri reshenii zadach neftyanoy geologii (Structuralformational characteristics of pre-Jurassic sediments of the north of West Siberia from seismo-geological analysis): Moscow, Nauka, 1988, p. 72-80 (Petroleum Geology, v. 30, no. 3, p 243-249).

Golonka, J., and Kiessling, W., 2002, Phanerozoic time scale and definition of time slices, in Kiessling, W., Flügel, E., and Golonka, J., eds., Phanerozoic reef patterns: Society of Economic Paleontologists and Mineralogists Special Publication 72, p. 11-20.

Golonka, J., Bocharova, N.Y., Ford, D., Edrich, M.E., Bednarczyk, J., and Wildharber, J., 2003, Paleogeographic reconstructions and basins development of the Arctic: Marine and Petroleum Geology, v. 20, p. 211-248. 
Gradstein, F.M., Ogg, J.G., and Smith, A.G., Agterberg, F.P., Bleeker, W., Cooper, R.A., Davydov, V., Gibbard, P., Hinnov, L.A., House, M.R., Lourens, L., Luterbacher, H.P., McArthur, J., Melchin, M.J., Robb, L.J., Shergold, J., Villeneuve, M., Wardlaw, B.R., Ali, J., Brinkhuis, H., Hilgen, F.J., Hooker, J., Howarth, R.J., Knoll, A.H., Laskar, J., Monechi, S., Plumb, K.A., Powell, J., Raffi, I., Röhl, U., Sadler, P., Sanfilippo, A., Schmitz, B., Shackleton, N.J., Shields, G.A., Strauss, H., Van Dam, J., van Kolfschoten, T., Veizer, J., and Wilson, D., 2004, A geologic time scale: Cambridge, U.K., Cambridge University Press, 589 p.

Grantz, A., Pease, V.L., Willard, D.A., Phillips, R.L., and Clark, D.L., 2001, Bedrock cores from $89^{\circ}$ Northimplications for the geologic framework and Neogene paleoceanography of Lomonsov Ridge and a tie to the Barents shelf: Geological Society of America Bulletin, v. 113 , no. 10 , p. 1272-1281.

Hardenbol, J., Thierry, J., Farley, M.B., Jacquin, T., de Graciansky, P.-C., and Vail, P.R., 1998, Mesozoic and Cenozoic sequence chronostratigraphic framework for European basins, in de Graciansky, P.-C., Hardenbol, J., Jacquin, T., and Vail, P.R., eds., Mesozoic and Cenozoic sequence stratigraphy of European basins: Society for Sedimentary Geology (SEPM) Special Publication 60, p. 3-13.

IHS Energy Group, 2007 [includes data current through October 2007], International exploration and production database: Englewood, Colo., IHS Energy Group [database available from IHS Energy Group, 15 Inverness Way East, D205, Englewood, CO 80112, U.S.A.].

Inger, S., Scott, R.A., and Golionko, B.G., 1999, Tectonic evolution of the Taimyr Peninsula, northern Russiaimplications for Arctic continental assembly: Geological Society of London Journal, v. 156, p. 1069-1072.

Kontorovich, A.E., Grebenyuk, V.V., Kuznetsov, L.L., Kulikov, D.P., Khmelevskiy, V.B., Azarnov, A.N., Nakaryakov, V.D., Polyakova, I.D., Sibgatullin, V.G., Soboleva, Ye.I., Starosel'tsev, V.S., and Stepanenko, G.F., 1994, Neftegazonosnye basseyny i regiony Sibiri, vypysk 3, Yenisey-Khatangskiy basseyn (Oil and gas bearing regions of the Siberia no. 3, Yenisei-Khatanga Basin): Novosibirsk, Russia, 71 p.

Lorenz, H., Gee, D.G., and Whitehouse, M.J., 2007, New geochronological data on Palaeozoic igneous activity and deformation in the Severnaya Zemlya Archipelago, Russia, and implications for the development of the Eurasian Arctic margin: Geological Magazine, v. 144, no. 1, p. 105-125.

Metelkin, D.V., Vernikovsky, V.A., Kazansky, A.Yu., Bogolepova, O.K., and Gubanov, A.P., 2005, Paleozoic history of the Kara microcontinent and its relation to Siberia and Baltica: paleomagnetism, paleogeography and tectonics: Tectonophysics, v. 398, p. 225-243.
Persits, F.M., and Ulmishek, G.F., 2003, Maps showing geology, oil and gas fields, and geologic provinces of the Arctic: U.S. Geological Survey Open-File Report 97-470-J, CD-ROM.

Scott, R.A., Torsvik, T.H., Eide, E.A., Walderhaug, H.J., and Andersen, T.B., 2003, Evolution of the Taimyr Peninsula (Arctic Siberia) and the implications for surrounding hydrocarbon basins [abs.]: American Association of Petroleum Geologists Annual Meeting, Salt Lake City, Utah, 2003, p. A154.

Sekretov, S.B., 2002, Structure and tectonic evolution of the Southern Eurasia Basin, Arctic Ocean: Tectonophysics, v. 351, p. 193-243.

Stepanenko, G.F., 1988, History of hydrocarbon reservoirs in the Anabar-Khatanga Saddle: Geologiya i Geofizika, 1988, v. 29, no. 2, p. 41-47 (Soviet Geology and Geophysics, v. 29 , no. 2, p. 37-42).

Torsvik, T.H., and Andersen, T.B., 2002, The Taimyr fold belt, Arctic Siberia - timing of prefold remagnetisation and regional tectonics: Tectonophysics, v. 352, no. 3-4, p. 335-348.

Uflyand, A.K., Natapov, L.M., Lopatin, V.M., and Chernov, D.V., 1991, The tectonic nature of the Taymyr Peninsula: Geotectonics, v. 25, no. 6, p. 512-523.

Ulmishek, G.F., and Klemme, H.D., 1990, Depositional controls, distribution, and effectiveness of world's petroleum source rocks: U.S. Geological Survey Bulletin B-1931, $59 \mathrm{p}$.

Vernikovsky, V.A., 1995, The geodynamic evolution of the Taimyr folded area: Tikhookeanskaya Geologiya, v. 14, no. 4 , p. $71-80$.

Vernikovsky, V.A., 1998, Taimyr fold area-evolution of the Earth crust and the main problems of tectonics [abs.]: Proceedings of the third International Conference on Arctic Margins, Celle, Germany, 1998.

Zonenshain, L.P., and Natapov, L.M., 1990, Tectonic history of the Arctic region from the Ordovician through the Cretaceous, in Herman, Y., ed., The Arctic seas - climatology, oceanography, geology, and biology: New York, Van Nostrand Reinhold, p. 829-862.

Zonenshain, L.P. [Zonenshayn, L.P.], Kuzmin, M.I., and Natapov, L.M., 1990, Geology of the USSR; a plate-tectonic synthesis (Geodynamics Series, v. 21): Washington, D.C., American Geophysical Union, 242 p. 


\section{Appendix. Input Data for the Northwest Laptev Sea Shelf Assessment Unit}

The appendix is available online only, and may be accessed at https://doi.org/10.3133/pp1824S

Menlo Park Publishing Service Center, California

Manuscript approved for publication March 18, 2016

Edited by George Havach

Layout and design by James Banton and Vivian Nguyen 


\section{$\frac{2}{2}$}

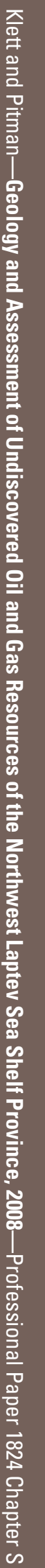

